ATLAS OF HUMAN ANATOMY I 


\section{ATLAS OF HUMAN ANATOMY}

BY

DR. FERENC KISS †

PROFESSOR EMERITUS

SEMMELWEIS UNIVERSITY MEDICAL SCHOOL

BUDAPEST
DR. JÁNOS SZENTÁGOTHAI

PROFESSOR

SEMMELWEIS UNIVERSITY MEDICAL SCHOOL BUDAPEST

VOLUME I

\section{OSTEOLOGY • ARTHROLOGY AND SYNDESMOLOGY MYOLOGY}

77TH EDITION

THIRD ENGLISH EDITION

IN COLLABORATION WITH

G.N.C. CRAWFORD

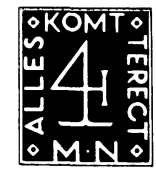

1980

MARTINUS NIJHOFF PUBLISHERS

THE HAGUE / BOSTON / LONDON 
Originally published as: $d r$. Kiss Ferenc-dr. Szentágothai János, Az ember anatómiájának atlasza, Medicina Könyvkiadó, Budapest, 1959.

The distribution of this book is handled by the following team of publishers:

\author{
for the United States \\ and Canada
}

Kluwer Boston, Inc.

160 Old Derby Street

Hingham, MA 02043

USA

for all other countries

Kluwer Academic Publishers Group

Distribution Center

P. O. Box 322

3300 AH Dordrecht

The Netherlands for Hungary, Albania, Bulgaria, China,

Cuba, Czechoslovakia,

German Democratic Republic,

Democratic People's Republic

of Korea, Mongolia, Poland,

Roumania, Soviet Union,

Democratic Republic of Vietnam, and Yugoslavia

Akadémiai Kiadó

P. O. B. 24

H-1363

Budapest

Hungary

Library of Congress Cataloging in Publication Data

CIP

Kiss, Ferenc, 1889-1966.

Atlas of human anatomy.

Translation of $\mathrm{Az}$ ember anatómiájának atlasza.

Bibliography: p.

Includes indexes.

CONTENTS: v. 1. Osteology. Arthrology and

syndesmology. Myology. - v. 2. Splanchnology.

Ductless glands. Heart. - v. 3. Nervous system.

Angiology. Sense organs.

1. Anatomy, Human-Atlases. I. Szentágothai,

János, joint author. II. Crawford, G.N.C.

III. Title.

QM25.K5413 $1979 \quad 611^{\prime} .002 ' 22 \quad 79-18296$

ISBN-13: 978-94-009-8816-3

e-ISBN-13: 978-94-009-8814-9

DOI: $10.1007 / 978-94-009-8814-9$

Joint edition published by

\section{MARTINUS NIJHOFF PUBLISHERS}

P. O. B. 566, $2501 \mathrm{CN}$ The Hague, The Netherlands

and

AKADÉMIAI KIADÓ

P. O. B. 24, H-1363, Budapest, Hungary

Copyright (C) Akadémiai Kiadó, Budapest, 1979

All rights reserved. No part of this publication may be reproduced, stored in a retrieval system, or transmitted in any form or by any means, mechanical, photocopying, recording, or otherwise, without the prior written permission of the publisher, Martinus Nijhoff Publishers bv, P. O. Box 566, 2501 CN The Hague, The Netherlands.

Softcover reprint of the hardcover lst edition 1979 